\title{
AN INVESTIGATION INTO THE ACUTE RESPIRATORY REACTION TO THE INHALATION OF TAMARIND SEED PREPARATIONS
}

\author{
BY \\ PETER G. TUFFNELL and I. DINGWALL-FORDYCE \\ From the Nuffield Department of Occupational Health, Manchester University
}

(RECEIVED FOR PUBLICATION JUNE 14, 1957)

An outbreak of cough and dyspnoea among workers in textile factories was recently reported by Murray, Dingwall-Fordyce, and Lane (1957). A new sizing agent prepared from the kernel of the seed of Tamarindus indica had been introduced and it was thought that the condition was a reaction to a constituent of this size.

The present investigation was designed to confirm that the illnesses were due to the size and to determine, if possible, the actual constituent responsible and the nature of the reaction.

\section{Method}

Four types of dust were used in the investigation: A, a modified starch, known as $\mathrm{K} 285$; $\mathrm{B}$, a mixture of $75 \%$ modified starch and $25 \%$ size, consisting of ground tamarind seed, tallow, sodium silico-fluoride, and betanaphthol; C, a mixture of modified starch and the preservatives, sodium silico-fluoride and betanaphthol in the same concentration as powder $\mathrm{B} ; \mathrm{D}$, a mixture of modified starch and pure tamarind flour.

A preliminary experiment was carried out in hospital with the cooperation of a velvet cutter, who had given a typical history of the condition. She was exposed first to powder A and 24 hours later to powder B. The powders were dispersed inside an oxygen tent by a small metal atomiser. Powder A (starch) produced no symptoms but a few hours after inhalation of powder B (containing tamarind) she complained of chest tightness and cough with purulent green sputum, her temperature rose to $100^{\circ} \mathrm{F}$, and physiological tests showed a marked decrease in respiratory efficiency. Symptoms cleared in two or three days. Bacteriological examination of the sputum on six separate occasions showed a normal flora.

Subsequent investigations were carried out with the aid of two groups of four volunteers. The first group were women weavers employed in the rayon mill which had been most affected by the condition. Each of them had had an illness which was thought to have been due to the new size. The second group, three men and one woman, had had no known previous exposure to any form of tamarind.
The powders were administered by the machine designed by Wright (1950) in which the dust is delivered through four corrugated tubes and mouthpieces. Respiratory function was estimated from the forced expiration over $0.75 \mathrm{sec}$. using a modified Gaensler apparatus (1951). The volume was multiplied by 40 to express results in $1 . / \mathrm{min}$. (Kennedy, 1953) as an indirect maximum volume ventilation (M.V.V.). The volunteers were given preliminary practice with this apparatus and throughout the experiment the means of the three highest readings recorded on each occasion were used for comparison. Eosinophil counts were made by the direct method.

The following routine was adopted for both groups in respect of M.V.V. measurements and for the unexposed group in respect of blood counts. Immediately before each inhalation, blood was taken for total white cell and eosinophil counts and M.V.V.s were estimated. These observations were repeated four hours later and again on the following morning. Control values for the second group were taken both during and six weeks after the end of the experiments. (This series comprised 72 blood counts and $144 \mathrm{M} . \mathrm{V} . \mathrm{V}$. determinations.) In order to discount errors due to diurnal variation the tests were always performed at the same time of day. Later in the experiment the afternoon eosinophil counts were omitted as it became obvious that no change occurred in so short a time. Temperatures were recorded morning and evening. (The weavers were given a thermometer and asked to take their temperature before going to bed and to bring the unshaken thermometer back the following morning.)

At the end of the experiment intradermal skin tests with increasing strengths of dilutions of the tamarind size up to $1: 100$ were carried out on the second group of volunteers.

\section{Results}

Reactions of Previously Exposed Subjects.-These subjects were not told the nature of any of the powders which they inhaled.

On the first day Powder A, modified starch, was used (Table 1). There was no subjective or objective 
effect. The M.V.V.s did not alter consistently, but showed individual variations from $+12 \%$ to $-9 \%$.

TABLE 1

MAXIMUM VOLUNTARY VENTILATION BEFORE AND FOUR HOURS AFTER INHALATION OF STARCH AND
TAMARIND SIZE BY PREVIOUSLY SENSITIZED WEAVERS

\begin{tabular}{c|c|c|c|c}
\hline & $\begin{array}{c}\text { M.V.V.at Start } \\
\text { of }\end{array}$ & \multicolumn{3}{|c|}{$\begin{array}{c}\text { M.V.V. before Powder } \\
\text { M.V.V. 4 hr. after }\end{array}$} \\
\cline { 3 - 5 } & $\begin{array}{c}\text { Investigation } \\
\text { (1./min.) }\end{array}$ & $\begin{array}{c}\text { Powder A } \\
\text { Starch } \\
(\%)\end{array}$ & $\begin{array}{c}\text { Powder B } \\
\text { Tamarind } \\
\text { Size } \\
(\%)\end{array}$ & $\begin{array}{c}\text { Powder A } \\
\text { Starch } \\
(\%)\end{array}$ \\
\hline 1 & 69 & 91 & 54 & 87 \\
2 & 94 & 112 & 60 & 79 \\
3 & 74 & 96 & 71 & 97 \\
4 & 105 & 101 & 75 & 99 \\
\hline \multicolumn{2}{|c|}{ Group } & $101^{*}$ & $66^{*}$ & $90^{*}$ \\
\hline
\end{tabular}

*Significantly greater decrease after Powder B $(\mathrm{P}<0.001)$

On the second occasion Powder B, diluted tamarind size, was used. Four hours after inhalation the M.V.V.s of all four subjects showed a sharp reduction. Subjective symptoms began at about the same time with breathlessness, chest tightness, cough, and headache. All became pyrexial, the evening temperatures ranging from $98.8^{\circ} \mathrm{F}$ to $102^{\circ} \mathrm{F}$. The following morning there was general complaint of an unpleasant and apparently characteristic taste in the mouth accompanied by dryness. In retrospect they all said that this symptom had been present during their illness in the mill. Greenish sputum produced by three of the subjects on the second day contained numerous polymorphs with a few eosinophils and on culture grew a normal bacteriological flora. The symptoms subsided rapidly although the taste and slight cough persisted for three to four days. On the fourth day a differential and total white cell count was normal in all the subjects.

After a second inhalation of Powder A, modified starch, no subjective or significant objective changes were observed.

The very considerable drop in the M.V.V. experienced by the group as a whole after inhalation of tamarind size was highly significant $(\mathrm{P}<0.001)$ when compared with the variation after starch powder.

Reactions of Subjects not Previously Exposed to Tamarind.-These subjects were first exposed to Powder B, diluted tamarind size, and a period of three weeks was allowed to elapse before the next dose. No clinical reaction followed either exposure. Inhalations of this powder were then continued twice weekly.

Subject No. 1 reacted clinically after the fourth dose. Four hours after exposure there was a marked decrease in the M.V.V., and he complained of lassitude. During the evening he had a temperature of $100 \cdot 8^{\circ} \mathrm{F}$. Twenty-four hours after exposure the eosinophil count had risen sharply and there was a proportionately smaller increase in the total white cells. Nine days later, having had no tamarind in the interval, he inhaled a quarter of the previous dose and reacted again in similar fashion.

The remaining subjects continued with the inhalations. After the seventh dose subject No. 2 developed headache, chest tightness and wheezing, and a slight cough. The M.V.V. dropped and he had a mild pyrexia of $98.8^{\circ} \mathrm{F}$. The same type and degree of reaction occurred on two further occasions, the second of which was after an interval of 22 days and was accompanied by a rise in eosinophils.

The two remaining subjects who had not yet experienced a measurable reaction continued to inhale the powder, the dose being gradually increased to four times the original level. After the twelfth dose subject No. 3 showed a drop in the M.V.V., pyrexia of $102.5^{\circ} \mathrm{F}$, eosinophilia, and leucocytosis. Subject No. 4 continued for a total of 20 exposures without developing any symptoms or signs.

Although none experienced a regular eosinophilia both the eosinophils and total white cells rose after every exposure in subjects 1 and 3 and during their first clinical reactions. These rises were highly significant $(P<0.001)$. No consistent variations occurred in the blood counts of either subject No. 2 or 4 , but after his third reaction subject No. 2 had a significant rise in eosinophils (Table 2).

TABLE 2

EOSINOPHIL AND TOTAL WHITE CELL COUNTS AFTER CLINICAL REACTIONS TO DILUTED TAMARIND SIZE

\begin{tabular}{|c|c|c|c|c|c|}
\hline \multirow{2}{*}{ Subject } & \multicolumn{3}{|c|}{ Control Readings } & \multicolumn{2}{|c|}{$\begin{array}{l}\text { Counts after Clinical Reactions } \\
\text { Shown as \% Ages of Control } \\
\text { Means }\end{array}$} \\
\hline & & $\begin{array}{c}\text { Eosino- } \\
\text { phils }\end{array}$ & $\begin{array}{l}\text { Total } \\
\text { White } \\
\text { Cells }\end{array}$ & Eosinophils & $\begin{array}{l}\text { Total White } \\
\text { Cells }\end{array}$ \\
\hline 1 & $\underset{\sigma}{\text { Mean }}$ & $\begin{array}{r}122 \\
32\end{array}$ & \begin{tabular}{l|}
7795 \\
1280
\end{tabular} & $\begin{array}{l}250^{*} \\
200 *\end{array}$ & $\begin{array}{l}140^{*} \\
118 \phi\end{array}$ \\
\hline 2 & $\underset{\sigma}{\text { Mean }}$ & $\begin{array}{r}582 \\
99\end{array}$ & $\begin{array}{l}7060 \\
1400\end{array}$ & $\begin{array}{l}105^{9} \\
93 \\
139^{*}\end{array}$ & $\begin{array}{r}112 \\
88 \\
115\end{array}$ \\
\hline 3 & $\underset{\sigma}{\text { Mean }}$ & $\begin{array}{r}140 \\
39\end{array}$ & $\begin{array}{r}5580 \\
890 \\
\end{array}$ & $\begin{array}{l}248^{*} \\
144^{*} \\
\text { (reduc }\end{array}$ & $\begin{array}{c}200^{*} \\
185^{*} \\
\text { d dose) }\end{array}$ \\
\hline
\end{tabular}

The M.V.V.s showed a significant variation from the control values only at the time of clinical reactions. The maximum decreases occurred about two to five hours after the inhalation of tamarind and were nearly, if not quite, normal by the following morning (Table 3).

When it had been shown that three subjects were 
TABLE 3

MAXIMUM VOLUNTARY VENTILATION DURING MAINICAL REACTIONS TO DILUTED TAMARIND CLINICAL REACTIONS TO

\begin{tabular}{c|c|c|c}
\hline Subjects & \multicolumn{2}{|c|}{ Controls } & $\begin{array}{c}\text { M.V.V.s (l./min.) during Clinical } \\
\text { Reaction } * \\
\text { (\% age of control means) }\end{array}$ \\
\hline 1 & $\begin{array}{c}\text { Mean } \\
\sigma\end{array}$ & $\begin{array}{c}176 \\
3 \cdot 2\end{array}$ & $\begin{array}{c}93 \\
92\end{array}$ \\
& Mean & 121 & $\begin{array}{c}\text { (reduced dose) } \\
86\end{array}$ \\
& $\sigma$ & 4.9 & 85 \\
& Mean & 100 & 71 \\
$\sigma$ & 4.0 & 76 \\
& & & 79 \\
& & & $\begin{array}{c}79 \\
\text { (reduced dose) } \\
\text { (Powder D) }\end{array}$ \\
\hline
\end{tabular}

* All these readings show a significant decrease $(P<0.001)$

sensitive to the whole size (Powder B) they inhaled Powder C, preservatives and starch without tamarind. No reaction ensued in any of the three. The dose was repeated and again no reaction occurred.

Pure tamarind flour diluted with starch, Powder D, was inhaled by subject No. 3. There was a reaction similar to this subject's first reaction to the whole size (Table 3).

The intradermal skin tests produced no reaction in any of the subjects.

\section{Discussion}

From epidemiological evidence tamarind size was thought to be responsible for acute respiratory symptoms in a high proportion of persons processing cloth treated with it. The reactions seemed likely to be allergic in nature since a period of exposure after an interval at home resulted in a rapidly induced reaction which was much more severe than the original illness.

Further evidence that the reaction was indeed due to the tamarind size has been the demonstration that four workers who had had an illness in the mill reacted violently to the inhalation of the tamarind size and not to a starch powder. On the other hand four persons who had never been exposed to tamarind were unaffected by a few doses of the powder but after a number of doses, varying in different individuals, reacted to an amount of powder that had not previously caused any effect. These results indicate an allergic rather than a toxic basis for the reaction; the negative skin tests in no way detract from this.
It has also been shown that it was the tamarind itself and not the other constituents of the size that was responsible for the reaction. This was demonstrated by the failure of known sensitive subjects to react to the other constituents and the positive reaction produced in one individual after inhalation of the pure tamarind powder.

The inhalation of tamarind powder by the previously unexposed subjects was of limited duration, being only for 15-minute periods, usually twice a week. Although the concentration of dust they inspired may have been higher than that of the workers in the mills it would not be expected that they would develop symptoms to the same degree as the workers, who inhaled the substance for many hours every day. In fact only one of the three developed respiratory symptoms, the reaction consisting in the others of pyrexia and objective changes in respiratory function and blood count. Despite this there seems no reason to doubt that the differences in the reactions between the two groups were of degree only.

\section{Summary}

An investigation, designed to trace the association between a respiratory illness in certain textile factories and the introduction of a new sizing agent, was carried out by means of exposing volunteers to variously constituted powders.

It was shown that the ingredient of the size which was responsible for the symptoms was the ground kernel of the seed of Tamarindus indica.

A period of exposure proved to be necessary before the induction of a reaction and indicated an allergic rather than a toxic basis.

We are much indebted to Professor R. E. Lane who carried out the preliminary experiment and initiated the investigation. We should like to thank Mr. E. Bradbury, of The Shirley Institute, who prepared the various powders; the volunteers whose cooperation made the investigation possible; the management of Glenfield Mills, Nelson; and Mr. Shaw, of the Nelson and District Weavers Association.

\section{REFERENCES}

Gaensler, E. A. (1951). Science, 114, 444

Kennedy, M. C. S. (1953). Thorax, 8, 73

Murray, R., Dingwall-Fordyce, I., and Lane, R. E. (1957). British

Journal of Industrial Medicine, 14, 105.
Wright, B. M. (1950). J. sci. Instrum., 27, 12. 